\title{
Early Childhood Education and Care in the United States: An Overview of the Current Policy Picture
}

\author{
Sheila B. Kamerman \\ Columbia University
}

USA

\author{
Shirley Gatenio-Gabel \\ Fordham University
}

USA

\begin{abstract}
Early childhood education and care (ECEC) in the US includes a wide range of part-day, full-school-day, and fullwork-day programs, under educational, social welfare, and commercial auspices, funded and delivered in a variety of ways in both the public and the private sectors, designed sometimes with an emphasis on the "care" component of ECEC and at other times with stress on "education" or with equal attention to both. Although ECEC scholars and advocates are increasingly convinced of the need to integrate all these program types, categorical funding coupled with diverse societal values continue to support the differences. The result is a fragmented ECEC system, of wideranging quality and with skewed access, but with some movement in recent years toward the integration of early childhood education and care.
\end{abstract}

Key Words : early education, child care, preschool

Increased attention to early childhood education and care (ECEC) has been observed in all the industrialized countries but our focus here is on a current picture of ECEC in the United States (U.S.).

Early childhood education and care (ECEC) in the U.S. includes a wide range of part-day, full-school-day, and full-work-day programs, under educational, social welfare, and commercial auspices, funded and delivered

Sheila B. Kamerman, Compton Foundation Centennial Professor for the Prevention of Children, Youth, and Family Problems at the Columbia University School of Social Work and Director of the Columbia University Institute for Child and Family Policy. 1255 Amsterdam Avenue, New York, NY 10027,U.S.A.sbk2@columbia.edu.

Shirley Gatenio-Gabel, Associate Professor Fordham University Graduate School of Social Services. in a variety of ways in both the public and the private sectors, designed sometimes with an emphasis on the "care" component of ECEC and at other times with stress on "education" or with equal attention to both. Although ECEC scholars and advocates are increasingly convinced of the need to integrate all these program types, categorical funding coupled with diverse societal values continue to support the differences. The result is a fragmented ECEC system, of wide-ranging quality and with skewed access, but with some movement in recent years toward the integration of early childhood education and care.

In what follows, we will identify and define the major program types, the context for current policy and program development, and the major issues. 


\section{Definitions $^{1}$}

The programs discussed here include preschools (kindergartens, pre-kindergartens, compensatory education programs, and nursery schools operated under education auspices), child care centers (often defined as programs in non-residential settings that provide education and/or care to children and include organized group programs such as Head Start) and family child care homes (both regulated and unregulated "child minding"). Parental care, relative care, occasional baby sitting (child minding) and care provided in a child's own home are not included in this paper nor are programs only for children with special needs.

\section{More Specifically}

Kindergartens are preschool programs for the year before primary school entry, largely for 5 year olds. They may be half day or full school day. In 1965, only eighteen states in the U.S. funded public kindergarten; by 1970 , eighty percent of five year olds attended public kindergarten and, in 2000, all states funded some sort of kindergarten, most universal. Kindergarten is a near universal experience now for American children, with about 98 percent of children attending kindergarten prior to first grade at least a half day, an essential introduction to primary school. About sixty percent attend a full school day program (Education Commission of the States, 2007; NCES, 2000). However, program content varies greatly across states.

Preschools (or nursery schools in US Census Bureau reports) include the range of programs offered under public and private education auspices or providing compensatory education under special legislation and are largely half-day or cover the normal school day (usually about 6 hours, e.g. 9:00am - 3:00 pm). By 1998 twentyeight states even funded some form of public prekindergarten education. (Kagan, 2005), and about the same number served 3 year olds. Only five states served more than 10 percent of that group in addition to child care centers and Head Start (see below). According to
Barnett in his review of the research (2007) "Research clearly shows that high-quality preschool education improves later school success, employment and earnings. It has lessened crime and delinquency and unhealthy behaviors like smoking and drug use. In economic terms, high-quality preschool has returned to the individual and the public up to $\$ 17$ on every $\$ 1$ invested." Head Start, the compensatory preschool program begun in 1965, is a federally funded preschool program, largely half-day, targeted on poor children and serving 3-4 year olds primarily. It provides comprehensive education, health, nutrition, social and other services and enrolled almost 1 million children in 2004, about half of those eligible for the program, 12 percent of the nation's 4-year olds and 8 percent of the 3-year olds. In 2004-05, $\$ 6.8$ billion were spent on Head Start.

Center-based child care typically refers to full-day programs under social welfare auspices or free-standing and independent programs that offer care corresponding to the traditional working hours (e.g.9:00 am to 5:00 pm or 7:00 am to $6: 00 \mathrm{pm}$ ), and are open five days a week for the full year. Although most centers provide care to children aged 3-5 years, some provide care for infants and toddlers (1-2 years of age) as well as those aged 3-5. The boundary between preschool and center programs is fuzzy, at best. At their discretion, some child care centers may care for school-age children as well in their after-school programs. Almost all centers are regulated or licensed in some way by the states with regard to health and safety standards, staff-child ratios, maximum number of children per group, nutrition and have at the least annual inspections.

Family child care refers to care for several children (other than the provider's own) in the caregiver's own home. About 11 percent of children under age 5 (and under age 3), with employed mothers, were cared for in this arrangement. States regulate family child care homes through licensing or registration on one or more of the following criteria: square footage for activities, staff-child ratios, pre-service training requirements, criminal backgrounds, and immunization requirements. Licensing typically requires providers to meet minimum 
health, nutrition and safety standards, limit the number of children in a home; and sometimes requires programmatic standards. Registration, by comparison, requires or encourages providers to self-identify themselves to the state and certify that they comply with state requirements. Registration typically involves fewer inspections than licensing. Family child care may provide care during standard hours or during irregular hours (e.g., nights or weekends). Group family day care homes are private homes that provide care for sometimes as many as 12 children, may be required to employ at least one other adult to assist in the care of the children, and are more likely to be licensed than family day care homes. The number of hours and days of care provided are negotiated between the parent and provider in these home-based settings, but are generally available to accommodate the needs of full-time working parents, full-year. Some states specify the maximum number of infants and toddlers that a provider can care for in their home.

ECEC policies currently include the whole range of government actions (federal, state, and sometimes local) to influence the supply and/or demand for ECEC and program quality. These government activities include: direct delivery of ECEC services; direct and indirect financial subsidies to private providers of education and care such as grants, contracts, and tax incentives; financial subsidies to parents/consumers of ECEC such as grants and tax benefits to permit or facilitate access to services or to permit parents to remain at home and withdraw from the labor force at the time of childbirth or adoption for a brief period of time; and the establishment and enforcement of regulations.

\section{ECEC Policy and Program Context}

Generally, ECEC policies cover children from birth through state-designated compulsory school age. Compulsory school age is determined by the individual state and ranges from age five through eight years. Elementary (primary) school is compulsory for all children but it is at the state's discretion whether or not kindergarten (the year before primary school begins) enrollment is mandated. Fourteen states and the District of Columbia, require children to attend kindergarten (Education Commission of the States, 2007). The other 36 states mandate the local school districts to provide kindergarten but it is the parents' decision whether or not to enroll their child. Parents also have the option of enrolling their children in privately sponsored kindergartens. Only 10 states are required to offer fullday kindergarten.

There is no debate, at present, regarding whether compulsory school age should be changed or even made fully consistent nationally. However, there is debate with regard to expansion of prekindergarten services and/or the length of the prekindergarten and kindergarten days and which level of government should have responsibility for regulation and the setting of program standards.

For most children in ECEC programs, entry into a formal early childhood program would be when children are between three and five years old. Because of growing evidence that early intervention can be effective in compensating for early deprivation, mitigating and preventing disabilities in the future, and helping prepare young children for subsequent schooling -and because more women with children under age 3 are entering the workforce- there have been increased resources dedicated recently to providing services to children under age 3. In addition to care and education, these

Table 1

Compulsory School Attendance Age across States in 2007

\begin{tabular}{cc}
\hline Compulsory School Attendance Age Number of States \\
\hline Age 5 years & 8 \\
Age 6 years & $\mathbf{2 2}$ \\
Age 7 years & $\mathbf{1 8}$ \\
Age 8 years & 2 \\
\hline
\end{tabular}

Note. From Education Commission of the States(2007). State Notes: Access to kindergarten: Age issues in state statutes. 
services may include health and nutritional screenings and may be coupled with family support services for parents including parent education, nutritional classes, various social service supports, and job training. There are specialized programs, also, which work with at risk populations, such as teens or substance abusers even prior to the birth of the child in preparation for parenting. Programs whose primary objective is to support the work efforts of parents accept children from three months of age (the maximum length of the federally mandated post-childbirth parental or family leave) through school age.

\section{Federalism: A Barrier to National Policy}

The U.S. has no coherent national ECEC policy. The primary responsibility for education is at the level of the states, not the Federal government, creating a barrier to the development of a national system of ECEC. The federal government, through the Congress, plays an important role in formulating ECEC policies and goals and facilitates the states' and localities 'major roles in the actual implementation of programs to suit the particular needs and preferences of their regions. The federal government's policy making efforts have primarily focused on making services available to children who are at risk, due to economic, biological, social, or psychological circumstances or combinations of these; providing child care services as an incentive for mothers receiving social assistance to gain entry to the labor force.

At the state level, policy decisions are made with regard to eligibility, extent of the supply and availability of services, allocation of services and benefits, scope and quality of services, including health and safety standards. At present, many state legislatures are taking a leading role in the development of ECEC policies, making larger investments in preschool programs and in programs that respond to the work responsibilities of poor families, especially those who are or are at risk of welfare (social assistance) dependency.

\section{Historical Roots}

As in most other advanced industrialized countries, ECEC programs in the U.S. evolved out of diverse historical streams including child protection, early childhood education services for children with special needs, and services to facilitate mothers' labor force participation. The "official" history of ECEC in the U.S. begins with two developments: (1) day nurseries (child care centers), first established in the 1830s under voluntary auspices and designed to care for the "unfortunate" children of working mothers; and (2) nursery schools, developing from the early education programs in Massachusetts also first established in the 1830s. Day nurseries expanded subsequently in response to pressures created by the rapid industrialization and massive immigration which took place in the latter part of the century. They were custodial in nature, focusing primarily on basic care and supervision of the children. During war times - the Civil War, World War I, and World War II-these programs increased in numbers, only to decline when war ended. Kindergartens and nursery schools expanded slowly during the $19^{\text {th }}$ century and experienced a significant increase only in the mid 1960s and early 1970s when a confluence of factors led to the significant expansion of both program types.

\section{Factors Affecting ECEC Developments}

Labor market policy, public (social) assistance policy, education policy, child welfare policy, and child development research all have had and have a role in the expansion of ECEC policies and programs.

Chief among these developments is the dramatic rise in the labor force participation of women, especially married mothers. The rise in the number of singlemother households has added to the demand, especially for full-day programs, since lone mothers are more likely than married mothers to work full time and female-headed families have been a rapidly growing family type.

A second major factor shaping ECEC policies at 
Table 2

Labor Force Status of Mothers with Own Children under 6, 1975-2005

\begin{tabular}{cccccc}
\hline & With Children Under 6 & Under 3 & 2 Years Old & 1 Year Old & Under 1 \\
\hline 1975 & 38.8 & 34.1 & 31.5 & $31.2(1977)$ & N.A. \\
1995 & 62.3 & 58.9 & 64.3 & 58.0 & 55.0 \\
2000 & 64.6 & 60.4 & 64.5 & 62.7 & 54.6 \\
2005 & 61.8 & 58.4 & 62.3 & 59.6 & 53.8 \\
\hline
\end{tabular}

Note. From Current Population Report, Bureau of Labor Statistics. Unpublished Tables.

present is the so-called "welfare reform" legislation of 1996, and the provisions of the new public assistance legislation for poor lone mothers and children. The Personal Responsibility and Work Opportunity Reconciliation Act of 1996 (PRWORA), requires that poor women with children aged 3 months and older "engage" in work within two years of claiming assistance and limits life-time receipt of assistance to a maximum of five years. These requirements mean that by far most poor lone mothers are now expected to work even when they have infants. One result has been increased Congressional recognition of the need for child care services, even if quality attributes and early education curricula have not received comparable attention.

Growing interest in primary "school readiness" is a third factor that has generated interest in ECEC in recent years. Research demonstrating the links that early learning experiences have with later school achievement, emotional and social well-being, fewer grade retentions, and reduced incidences of juvenile delinquency, are all factors associated with later adult productivity, and suggest the value of increased "investment" in ECEC (Barnett, 1995; Berrueta, 1984; Lazar, 1983; Yoshikawa, 1995; Currie, 2000; Brooks-Gunn, 2003; Hechman \& Masterov, 2007). From this perspective, ECEC is increasingly viewed as a cost efficient and cost effective strategy whose benefits are reaped both during the school careers of each child, in their later life, and in the future economy.

\section{Conflicting Values/Divergent Purposes}

American society has long been conflicted in its attitude towards women and their proper roles and in its attitude towards government and the family and their appropriate roles. This tension emerges repeatedly in discussions regarding ECEC policies. Poor single mothers are expected to work outside the home and, despite a very different reality, there are many who still believe that middle class mothers should remain at home. Government's involvement in the rearing of children is still viewed by some as trespassing into the private lives of its citizens.

ECEC responds to the changing work roles and composition of families, helps to equalize life opportunities for children in low-income families, assists in the assimilation of immigrants, and aids in enhancing child development and child wellbeing generally. Early on, publicly provided ECEC was designed to accommodate the social needs of vulnerable children, the educational needs of all young children, and the needs of working parents. Child care and early education developed separately, historically, and are still not well integrated. Through the years the two major functions of care and education have remained separate and often viewed as conflicting. One result has been the development of a wide and disparate range of ECEC programs of varying quality.

\section{Issues}

\section{The Public/Private Mix}

As with regard to most social services in the U.S., the private sectors (both non-profit and for-profit) play a 
major role in ECEC. For example, of all five year olds enrolled in kindergarten in 2003, 83 percent attended public kindergarten programs and 17 percent attended private programs. About half the children in nursery schools are in private schools. More important, private providers continue to dominate the delivery system: Family day care is almost all private. Of the three-year olds in preschool programs, most are in private programs but by age five, the overwhelming majorities are in public preschools.

Publicly-funded preschool programs typically serve children from disadvantaged families, while private preschool programs supported by parent fees are more likely to serve children from all backgrounds and the focus is more on the child than on providing support to the family.

Some employers, usually large firms, have become involved in ECEC typically by providing links with ECEC information and referral services, and to a lesser extent by becoming a provider of services to their employees. Such firms may offer employee subsidies or other benefits for child care, providing financial support to early childhood centers in the community, and participating in local or state collaborations to plan for future early childhood needs. Charitable foundations are important players in the policymaking arena through their funding of research and innovative programming; and religious organizations also play a significant role in ECEC service delivery.

\section{Access and Coverage}

In 2002, 11.6 million children or 63 percent of the 18.5 million infants, toddlers and preschool children under age 5, were receiving some type of care other than from their parents on a regular basis (U.S. Census, 2005a). The type of care a family decides to place their child in is dependent on a family's income, family structure and ethnicity, age of child, maternal education, maternal employment and attitudes toward early care. Where poor single mothers are concerned, or employed parents, the need for care may begin in infancy or even when the child is three months old, because the U.S. has only a brief (three months) and unpaid parental leave following childbirth. ${ }^{2}$ Children of mothers who are college graduates were substantially more likely to attend nursery school (preschool and center-based programs) in 2003 than children whose mothers did not finish high school (64 percent compared with 34 percent). (U.S. Bureau of the Census, 2005b). Similarly, in 2003, 62 percent of 3 and 4 year olds from families with incomes of $\$ 50,000$ or more attended nursery school, compared with 41 percent of those from families with incomes less that $\$ 20,000$.

Although kindergarten coverage is essentially universal now, largely for 5-year olds, for the year before entering primary school, states vary in their provision of full and part-day kindergarten programs. About half of all kindergartners now attend full (school)day programs (U.S. Census, 2005a).

At four years of age, the proportion of children enrolled in center-based care rose to 69.2 percent,. Including kindergarten and primary school, almost 98 percent of 5 year olds are in some form of school or preschool) and of these, more than 75 percent are in kindergarten; the remainder are in primary school or center care.

Forty-four states now provide pre-kindergarten programs at least in some jurisdictions. Only three states, Florida, Georgia, and Oklahoma, however, approach offering a state-wide program of universal preschool for all four year olds.

\section{Coverage for the Under $3 \mathrm{~s}$}

About 60 percent of the under $3 \mathrm{~s}$ had mothers in the labor force in 2006. Programs serving children under the age of three, generally focus on supporting the work efforts of parents. Yet despite this, ECEC programs serving children under the age of three are in short supply. Few states serve 3 year olds in pre-kindergarten programs, but 43 percent of 3 year olds are in centerbased care. By the time a child reaches age three, parental preference for school- or center-based settings 
is striking.

In addition to child care programs, family support programs, sometimes also included with other ECEC programs, offer drop-in child care, information and referral services, weekly or monthly home visits and parenting classes aimed at strengthening parenting skills, and so forth. They commonly serve families with children under the age of three (though they may include older children) and some strive to link programs for children with parental supports, such as job training and education. These programs target low-income groups primarily and involve a caseworker to link services that are provided by other community agencies. Typically, they rely on public funds and private foundation support and provide services at no charge to their client families. Also typically, these programs target families in or at risk of poverty, teen parenthood, welfare dependency or are in immigrant groups struggling with acculturation issues (Gomby, 1995).

Half of the infants born in 2001 were in some kind of regular non-parental child care arrangement at 9 months of age (Kreader, Fergusson, \& Lawrence, 2005). Most parents of infants choose informal or in-home care. For children under the age of one year, 26 percent were cared for by a relative (often a grandmother), 11 percent were in family day care homes, and 9 percent in centerbased care settings.

The age at which families first place their children in care depends on the work status of the mother, household income and maternal education. Families more dependent on a mother's income are more likely to place infants in care at an earlier age and use more hours of care than families less dependent on maternal income. Poor mothers might place their infants in care even earlier than three months. Poor children who are enrolled in center-based programs receive care of the quality equal to affluent children. Poor children who do not enter care by their first birthday are more likely to come from large families, experience persistent poverty, and have mothers with the least education. In contrast,

Table 3

Percentage of children under 6 years old in type of ECEC, by age 1 Type of Non-Parental Arrangement

\begin{tabular}{|c|c|c|c|c|c|c|}
\hline & Children & Total & $\begin{array}{l}\text { In-Relative } \\
\text { Care }\end{array}$ & $\begin{array}{c}\text { In Non- } \\
\text { Relative Care }\end{array}$ & $\begin{array}{l}\text { In Center- } \\
\text { Based } \\
\text { Program }\end{array}$ & $\begin{array}{l}\text { No Non- } \\
\text { Parental } \\
\text { Arrangement }\end{array}$ \\
\hline Characteristic & (In thousands) & $\begin{array}{c}\text { (Percent in } \\
\text { non-parental } \\
\text { care) }\end{array}$ & Percent & Percent & Percent & Percent \\
\hline TOTAL & 21,421 & 60 & 21 & 18 & 31 & 40 \\
\hline \multicolumn{7}{|l|}{ Age/3 } \\
\hline Less than 1 year & 4,158 & 45 & 24 & 17 & 7 & 55 \\
\hline 1 years old & 4,027 & 50 & 24 & 19 & 11 & 50 \\
\hline 2 years old & 4,007 & 54 & 19 & 20 & 19 & 46 \\
\hline 3 years old & 4,126 & 68 & 21 & 19 & 41 & 32 \\
\hline 4 years old & 4,065 & 78 & 18 & 15 & 65 & 22 \\
\hline 5 years old & 1,038 & 84 & 15 & 17 & 75 & 16 \\
\hline
\end{tabular}

Note. Estimates are based on children under 6 not yet in kindergarten in the 1995 NHES.

Note. Columns do not add up to total because some children participated in more than one type of arrangement. From Child Care and Early Education Program Participation of Infants, Toddlers, and Preschoolers, by U.S. Department of Education. 
Table 4

Number of preschool children under 6 years old, percentage in center-based programs, non-parental care, and percentage in various types of primary care arrangements, 2005

\begin{tabular}{|c|c|c|c|c|c|c|c|}
\hline $\begin{array}{l}\text { Child and family } \\
\text { characteristic }\end{array}$ & $\begin{array}{c}\text { Number of } \\
\text { children, ages } \\
0 \text { to } 5 \text { (in } \\
\text { thousands) }\end{array}$ & $\begin{array}{c}\text { Percent in } \\
\text { center-based } \\
\text { programs }\end{array}$ & Head Start & $\begin{array}{l}\text { Other } \\
\text { center- } \\
\text { based }\end{array}$ & $\begin{array}{l}\text { Parental } \\
\text { care only }\end{array}$ & $\begin{array}{c}\text { Family child } \\
\text { care }\end{array}$ & Relative \\
\hline $\begin{array}{l}\text { Total preschool } \\
\text { children }\end{array}$ & 20,665 & 36.1 & 5.1 & 27.3 & 39.8 & 8.3 & 15.4 \\
\hline \multicolumn{8}{|l|}{ Age } \\
\hline Under 1 year & 3,519 & 12.0 & 1.2 & 10.0 & 57.7 & 9.2 & 17.2 \\
\hline 1 year old & 3,988 & 16.9 & 0.7 & 15.0 & 48.5 & 11.1 & 19.1 \\
\hline 2 years old & 4,093 & 28.7 & 3.5 & 22.7 & 44.9 & 10.7 & 14.3 \\
\hline 3 years old & 4,070 & 42.5 & 5.3 & 33.2 & 34.0 & 7.6 & 16.7 \\
\hline 4 years old & 3,873 & 69.2 & 13.2 & 48.2 & 20.9 & 4.0 & 10.4 \\
\hline 5 years old & 1,123 & 68.7 & 10.4 & 48.4 & 21.1 & 4.6 & 13.6 \\
\hline
\end{tabular}

Note. From Digest of Education Statistics, 2006.

mothers who earn the highest incomes were most likely to place their children between 3 to 5 months and to use in-home non-relative care for the first 15 months (NICHD, 1999).

\section{Quality}

There is no agreed on definition of -or standards concerning- quality of ECEC programs across both school-based pre-kindergarten programs and centerbased and Head Start programs. Indicators of quality in centers continue to include: staff: child ratios; group size; caregiver qualifications (education and training), staff salaries; and turnover rates - among the dimensions of quality that can be counted and regulated, and staffchild interactions and relationships among those variable that require direct observation.

Despite research demonstrating that high quality early childhood care and education can be beneficial to children, research has also demonstrated that the majority of children in the United States are placed in low quality care, some of which may be detrimental to the long-term development of children (Helbrun, 1995; NICHD, 1998; Whitebook, 1989). Some states set high quality standards and monitor programs closely, while others place quality control at the local level. The scope and depth of programming varies greatly both across and within states, from comprehensive programs promoting health, social and cognitive development to others providing limited opportunities for social interaction and developmental stimulation. In some states, prekindergarten programs are administered by the state's department of education and in others governance is deferred to local school districts, thus adding further to the variation. Some programs have responded to the needs of working families by extending hours, coordinating with other programs for a full-day of programming, or parents have made arrangements for children to be transported to other private programs. Transferring young children from one program to another creates further complexities and is less preferred (Mitchell, Ripple, \& Chanana, 1998).

According to the 2006 State Preschool Yearbook, about one million children participated in state pre- 
kindergarten programs in 2005-2006. Barnett et al. (2006) note that the quality of these preschools ranges from excellent to poor and, as we have already seen, funding and access vary from state to state. Preschool quality improved in recent years as more states adopted comprehensive learning standards for their prekindergarten programs. Nonetheless, quality continues to vary across states. For example, 20 states did not require pre-kindergarten teachers to have completed a Bachelor's degree. Ten states did not require teachers to have had special training for ECEC programs. And per child spending for pre-kindergarten was significantly lower than for grades $\mathrm{K}-12$ in primary school, with pre-K teachers being paid significantly less that for primary school.

\section{Funding}

The different histories, sources and levels of public investment perpetuate a false dichotomy in polices for ECEC programs. Federal funding for ECEC totaled more than $\$ 17$ billion in 2005 . It should be noted, however, that fees paid by parents for ECEC cover about 70 percent of the operating costs of these programs in the U.S.

The major federal sources of child care funds include the following: The Child Care and Development Fund (CCDF) provides funding to the states to subsidize the child care expenses of working parents whose family income is less than 85 percent of the state median income, as well as for activities related to the improvement of the overall quality and supply of child care in general. Federally it is administered by the Administration for Children and Families (ACF) in the Department of Health and Human Services (DHHS). At the state level, it is administered by the agency responsible for social service/welfare administration or employment related activities. In 2006 , over $\$ 5$ billion was appropriated for this block grant, matched by state funds totaling $\$ 2.2$ billion and the transfer of funds from "welfare" (the Temporary Assistance to Needy Families program) of almost $\$ 1.2$ billion (Child Care Bureau,
2007).

The Child and Dependent Care Tax Credit in the Internal Revenue Code is a nonrefundable tax credit for expenses related to the care of a dependent child less than 13 years old, or a mentally or physically incapacitated spouse or dependent. In 2006, the maximum credit for one dependent was 35 percent of the first $\$ 3,000$ spent on the care of one child and $\$ 6,000$ for two or more. In 2005 , the tax credit was valued at $\$ 2.7$ billion. The tax credit is administered by the U.S. Department of Treasury, Internal Revenue Service.

Head Start funds direct grants to local programs providing comprehensive early childhood development, educational, health, nutritional, social and other services to primarily low-income preschool-aged children and their families. Most Head Start programs are part-day through the school year, though some local grantees coordinate with other programs to provide full-day care. Head Start is federally administered by the Administration on Children and Families (ACF) at DHHS. In 2005 it was funded at $\$ 6.9$ billion, and served about 900,000 children, largely three and four year olds. A small number of children under age three are now enrolled in an Early Head Start program.

The Social Services Block Grant (SSBG, Title XX of the Social Security Act) provides grants to states for social services, which most states draw on for at least a portion of their ECEC services. The grants are federally administered by ACF at DHHS at about $\$ 400$ million in 2005.

The Child and Adult Care Food Program provides federal subsidies for breakfasts, lunches, suppers, and snacks meeting federal nutrition requirements that are served in licensed child care centers, schools, and group and family day care homes to children age 12 or under. It is administered by the U.S. Department of Agriculture's Food and Nutrition Service and was funded at \$2.1 billion in 2005 .

Several other federal programs such as the Individuals with Disability Education Act (IDEA) provide funding for ECEC as well. IDEA established an entitlement to special education services for children 
ages three through 21 with disabilities.

Local school districts may also use other categorical federal funds to support preschool education and school-age child care in districts serving a high percentage of low-income children. Once such program, Even Start, provides grants to schools for familycentered education to help parents of educationally disadvantaged students' ages one through seven become full partners in their children's education. Funding is also available from the $21^{\text {st }}$ Century Community Learning Centers program for grants to rural and inner city public schools to address educational and community needs during after school hours, weekends, and summers.

\section{Administrative Responsibilities}

The Administration for Children and Families (ACF), within the federal Department of Health and Human Services (HHS) is responsible for federal programs which promote the economic and social wellbeing of families, children, individuals, and communities. One agency in ACF is the Child Care Bureau which was established in January 1995 to administer federal child care programs to states, territories and tribes for lowincome children and families. The Bureau has initiated a variety of activities to improve the quality, availability and affordability of child care across the country. Education dollars flowing into early education programs in schools are administered by the U.S. Department of Education. Among its priorities are to supplement and complement the efforts of states, the local school systems, the private sector, public and private nonprofit educational research institutions, community-based organizations, parents, and students to improve the quality of education.

Most programs that channel federal funds to state governments are administered by their state counterparts to the federal agencies. Some states have established interagency collaborations similar to that on the federal level to enhance the coordination of early childhood education and policy.
Outside of government there are hundreds, perhaps even thousands, of private advocacy, think-tanks, research, outreach, university, foundation, and public policy institutions in the United States interested in early childhood education and care policies. Periodically, experts are convened at a national forum to debate issues related to early childhood education and care. Experts at these institutions interact with government officials on a formal and informal basis at privately and publicly sponsored conferences, public hearings, and throughout the legislative and budgetary process. The efforts at the federal level are mirrored in the individual states and in metropolitan areas.

\section{Conclusions}

Interest in and participation in out-of-home, nonparental child care has increased dramatically in the U.S. over the last few decades, as has policy attention and public funding. The pressures from employed mothers with young children continue to rise, and underscore the need for more accessible, affordable, and better quality ECEC services. The U.S. has carried out more extensive and more rigorous research on the impact of this dramatic change in how young children are reared and cared for than any other country. The hoped-for outcomes now include: the productivity of the current and future workforce; the prevention and reduction of social problems such as welfare dependency, juvenile delinquency, teen pregnancy, and school failure; support for the work, efforts of welfare-dependent and poor parents to help them achieve economic self-sufficiency; enhancing the development of young children; and helping parents fulfill their roles as nurturers and teachers to their children by providing skill training (Kamerman, 2001). International ECEC developments, especially in the European Union and in other OECD countries have far outpaced what exists in the U.S.

Preschool for 5 year olds in the form of kindergarten and a one year preparation for primary school is now taken for granted as being a universal 
experience, and increasingly covering a full school day. Preschool for 4 year olds is moving in this direction, albeit beginning with disadvantaged children first, and a debate continues as to whether public support should aim for universal coverage, or remain limited to the poor. Preschool for the 3 year olds is beginning to gain more attention, but infant and toddler care is still very limited, and largely in the form of informal care; and in contrast to other industrialized countries does not include a paid and job-protected parental leave as an option for infant care. 3 Federal funding has increased significantly since the mid-1990s, but is still inadequate to meet the need for decent quality, affordable care, and remains largely categorical. We know what high quality ECEC is and how important it is, yet most programs reflect at best, mediocre quality. Staff is often not in receipt of appropriate training, and when they are, may still not be paid adequately. Most important, of greatest concern, is the fragmented delivery system, still largely private and so divided between "care" and "education", that even. Data on access, coverage, and funding is difficult to disaggregate.

\section{References}

Barnett. W. S. (1995). Long-term effects of early childhood programs on cognitive and school outcomes. The Future of Children Long-Term Outcomes of Early Childhood Programs, 5(3), 2550.

Barnett, W. S. (2007). Early education: A sound public investment. Paper presented at the 2007 Tennessee Early Childhood Summit. Retrieved October 4, 2007, from http://www.state.tn.us/education/prek/ documents/Early_ED_Invest.pdf.

Barnett, W. S., Hustedt, J., Hawkison, L., \& Robin, K. (2006). The state of preschool 2006. National Institute for Early Education Research.

Barnett, W. S., \& Robin, K. (2006). How much does quality preschool cost? National Institute for Early Education Research. Retrieved October 4, 2007, from http://nieer.org/resources/research/CostOf Effec tive Preschool.pdf.

Berreuta-Clement, J. R., Schweinhart, L., Barnett, W. S., Epstein, A., \& Weikart, D. P. (1984). Changed lives: The effects of perry preschool program on youths through age 19. Monographs of the High/Scope Educational Research Foundation, 8. Ypsilanti, MI: High/Scope Press.

Brooks-Gunn, J. (2003). Do you believe in magic? What we can expect from early childhood intervention programs. Society for Research in Child Development, 17(1), 1-14.

Currie, J. (2000). Early childhood intervention programs. What do we know? Joint Center for Poverty Research (Working Paper No. 169).

Gomby, D. S., Larner, M. L., Stevenson, C. S., Lewit, E. M., \& Behrman, R. E. (1995). Long-term outcomes of early childhood programs: Analysis and recommendations. The Future of Children, 5(3), 624.

Gormley, W., Jr. (2005). The Universal Pre-K Bandwagon. Phi Delta Kappan, 87(3).

Hechman, J. J., \& Masterov, D. V. (2007). The productivity argument for investing in young children. Cambridge, MA: National Bureau of Economic Research.

Helburn, S. (Ed.). (1995). Cost, quality and child outcomes in child care centers (Tech. Rep.) Denver: University of Colorado, Department of Economics, Center for Research in Economic Social Policy.

Kagan, S., \& Stewart, V. (2005). Education in a global era [Special issue]. Phi Delta Kappan, 87(3).

Kamerman, S. B. (Ed.). (2001). Early childhood education and care: International perspectives. New York: Columbia University, ICFP.

Kreader, J., Fergusson, D., \& Lawrence, S. (2005). Infant and toddler child care arrangements. National Center for Children in Poverty.

Lazar, I., Darlington, R., Murray, H., Royce, J., \& Snipper, A. (1983). As the twig is bent. New Jersey: Erlbaum Associates.

Mitchell, A., Ripple, C., \& Chanana, N. (1998, 
September). Prekindergarten programs funded by the states: Essential elements for policy makers. New York: Families and Work Institute.

National Center for Education Statistics. (1997). The Condition of education, 1997. U.S. Department of Education.

National Center for Education Statistics. (2006). Digest of education statistics. U.S. Department of Education.

National Center for Education Statistics. (2006, October).

Child care and early education program participation of infants, toddlers, and preschoolers.

U.S. Department of Education.

National Center for Education Statistics. (2006). Condition of education, Early Childhood Program Enrollment. U.S. Department of Education.

National Institute on Child Health and Human Development. (1998). The childcare network. Washington, DC: NICHD.

Stoney, L., \& Greenberg, M. (1996). The financing of child care: Current and emerging trends. The Future of Children, 6 (2), 83-102.

U.S. House of Representatives. (1998). Committee on ways and means, The green book. Washington, DC: Government Printing Office.

U.S. Bureau of the Census Current Population Report. (2005a). Who's minding the kids? Childcare arrangements: Winter 2002. Washington, DC: Government Printing Office.

U.S. Bureau of the Census. (2005b). School enrollmentSocial and economic characteristics of students: October 2003. Washington, DC: Government Printing Office.

Whitebook, M., Howes, C., \& Phillips, D. (1989). Who cares? Child care teachers and the quality of care in America: Final Report, National child care staffing study. Oakland, CA: Child Care Employee Project.

Yoshikawa, H. (1995). Long-term effects of early childhood programs on social outcomes and delinquency. The Future of Children, 5(3), 51-75.

\section{Note}

1 These definitions were drawn from Sheila B. Kamerman and Shirley Gatenio-Gabel, ECEC: "An Overview of the Current Policy Context” Debby Cryer \& Richard M. Clifford, eds. Early Childhood Education \& Care in the USA. Baltimore: Brooks, 2003, a version of the background paper prepared for the OECD Thematic Review of ECEC policies and programs.

2 The Family and Medical Leave Act (FMLA) was enacted in 1993 and provided for a 12 week job-protected but unpaid leave for employees in firms with 50 or more workers, at the time of pregnancy, childbirth, or their own illness or that of a family member. Employers can require that employees use their vacation and sick leave before claiming the family leave.

${ }^{3}$ A few states have begun to move in this direction, but even in such states, for example, California, the leaves remain very brief. 